\author{
Agata Marcysiak \\ Adam Marcysiak \\ Wydzial Nauk Ekonomicznych i Prawnych \\ Uniwersytet Przyrodniczo-Humanistyczny w Siedlcach
}

\title{
Zarządzanie majątkiem jednostek gospodarczych o różnym potencjale ekonomicznym
}

\section{MANAGEMENT OF ECONOMIC ASSETS WITH VARIOUS ECONOMIC POTENTIAL}

\begin{abstract}
Celem niniejszego opracowania jest próba ukazania zakresu zarządzania majątkiem podmiotów gospodarczych o różnym potencjale ekonomicznym. Materiałem badawczym były dane o gospodarstwach charakteryzujacych się zróżnicowanq wielkościq ekonomiczna, które prowadziły rachunkowość rolnq dla potrzeb Instytutu Ekonomiki Rolnictwa i Gospodarki Żywnościowej. Majatek gospodarstwa przedstawiono w formie syntetycznej jako sumę dwóch grup aktywów: trwatych i obrotowych. W obrębie aktywów trwatych analizie poddano cztery sktadniki a w przypadku aktywów obrotowych trzy skladniki. Dla oceny efektów działań zarzqdczych analizie poddano produktywność $i$ dochodowość podstawowych czynników produkcji. Najwyższym poziomem dochodowości odznaczaty sie gospodarstwa o wielkości ekonomicznej 100-500 tys. Euro. Istotnym parametrem efektywności gospodarowania byt wskaźnik rentowności kapitalu własnego ROE. Dodatnia jego wartościq odznaczały się gospodarstwa o wielkości ekonomicznej powyżej 25 tys. Euro. Wyższa rentowność poprawiała perspektywy rozwojowe gospodarstwa i sprawiała, że więcej środków można było przeznaczyć na zakup poszczególnych składników majatku.
\end{abstract}

Słowa kluczowe: majątek trwały i obrotowy, wielkość ekonomiczna, zarządzanie majątkiem, efektywność gospodarowania.

\section{Wprowadzenie}

Prowadzenie działalności gospodarczej wiążę się z wieloma obowiązkami. Zakres odpowiedzialności dotyczy szczególnie zadań związanych z zarządzaniem majątkiem¹. Specyfiką produkcji rolniczej jest ścisły związek z przyrodniczymi warunkami produkcji. Rolnicy, dążąc choćby do częściowego uniezależnienia się od warunków zewnętrznych, zmuszeni są do ponoszenia znacznych nakładów finansowych skierowanych na zakup środków trwałych służących osłonie niektórych procesów produkcyjnych. Rodzi to konieczność inwestowania w budynki i budowle zarówno o charakterze produkcyjnym jak i pomocniczym² .

Inną specyfiką produkcji rolniczej jest zróżnicowanie zabiegów ze względu na różnorodność produkcji oraz pór roku. To z kolei zmusza rolników do wyposażania gospo-

\footnotetext{
${ }^{1}$ J. Grzywacz (red): Zarządzanie majątkiem obrotowym w przedsiębiorstwie. SGH Warszawa 2006, 57-71.

${ }^{2}$ E Niedzielski, B Fedejko: Zarządzanie strategiczne przedsiębiorstwem rolniczym. Wyd. ART. Olsztyn 1995, 26-31.
} 
darstw w różnorodny sprzęt techniczny (maszyny, narzędzia i środki transportu), który niejednokrotnie wykorzystywany jest zaledwie przez kilkanaście, a nawet kilka dni w roku. Wiąże się to $\mathrm{z}$ wysokim udziałem środków trwałych w większości gospodarstw, co nie pozostaje bez wpływu na okres zwrotu zainwestowanych w nie środków finansowych oraz rezultaty produkcyjne i finansowe prowadzenia gospodarstw ${ }^{3}$.

Rolnicy, dążąc do poprawy swojej sytuacji finansowej, inwestują w środki trwałe, zwracając większą uwagę na ich ilość i ewentualnie jakość, mniejszą wagę przywiązując do ich efektywnego wykorzystania. Często więc gospodarstwa, zwłaszcza te o mniejszym potencjale produkcyjnym, są przeinwestowane, a okres zwrotu środków finansowych zainwestowanych w środki trwałe jest bardzo długi ${ }^{4}$. Cechą charakterystyczną większości gospodarstw rolnych w Polsce jest wysoka wartość środków trwałych w stosunku do posiadanego obszaru użytków rolnych oraz wysoki udział środków trwałych w wartości aktywów ogółem.

Istotnym parametrem oceny siły ekonomicznej i potencjału produkcyjnego gospodarstw w UE jest wielkość ekonomiczna. Określana jest ona na podstawie sumy Standardowych Produkcji uzyskanych ze wszystkich działalności rolniczych występujących w danym gospodarstwie rolnym. Wyrażana jest ona bezpośrednio w euro.

\section{Metodyczne aspekty opracowania}

Celem niniejszego opracowania jest próba ukazania zakresu zarzadzania majątkiem podmiotów gospodarczych o różnym potencjale ekonomicznym.

Materiałem badawczym były dane o gospodarstwach charakteryzujących się zróżnicowaną wielkością ekonomiczna, które prowadziły rachunkowość rolną dla potrzeb Instytutu Ekonomiki Rolnictwa i Gospodarki Żywnościowej. Szczegółową analizą objęto rok 2016.

Podstawowymi kategoriami ekonomicznymi, przyjętymi dla potrzeb procesu badawczego były: wartość produkcji ogółem oraz poziom dochodu z gospodarstwa rolniczego Obliczeń tych kategorii dokonano metodą stosowaną w europejskim systemie rachunkowości rolnej FADN (Farm Accountancy Date Network) ${ }^{5}$.

Majątek gospodarstwa przedstawiono w formie syntetycznej jako sumę aktywów trwałych i obrotowych. W obrębie aktywów trwałych analizie poddano cztery składniki a w przypadku aktywów obrotowych trzy składniki.

Dla oceny efektów działań zarządczych analizie poddano produktywność i dochodowość podstawowych czynników produkcji. Produktywność obliczono jako wartość produkcji rolniczej przypadającą na 1 ha UR, na 1 jednostkę przeliczeniową pracy AWU i na 1000 zł wartości rzeczowych środków trwałych i obrotowych. Dochodowość ukazano jako wartość dochodu z gospodarstwa rolniczego przypadającą na 1 ha UR, na 1 jednostkę przeliczeniową pracy AWU i na 1000 zł wartości rzeczowych środków trwa-

\footnotetext{
${ }^{3}$ S. Mańko, R. Płonka: Struktura aktywów a wyniki działalności gospodarstw rolnych w świetle danych polskiego FADN Zagadnienia Ekonomiki Rolnej nr 4 (325) Warszawa 2010, 134-145.

${ }^{4}$ L. Goraj, S. Mańko: Rachunkowość i analiza ekonomiczna w indywidualnym gospodarstwie rolnym. Difin, Warszawa 2009, 185-209.

${ }^{5}$ Z Floriańczyk, B. Malanowska, D. Osuch, M. Bocian: Opis realizacji planu wyboru próby gospodarstw rolnych dla Polskiego FADN. IERiGŻ, Warszawa 2017, s. 8-15.
} 
łych i obrotowych. Poszczególne wielkości ukazano w przeliczeniu na jedno gospodarstwo w zł. Skalę zróżnicowania przedstawiono w ujęciu procentowym.

\section{Charakterystyka badanych gospodarstw}

Średni obszar badanego gospodarstwa w 2016 roku wynosił 19,5 ha UR. Analizowane gospodarstwa reprezentowały różną wielkość ekonomiczną. W próbie badawczej polskiego FADN liczącej 12302 gospodarstw dominującymi były gospodarstwa o wielkości ekonomicznej 8-25 tys. Euro. Ich udział wynosił 34,0 \%. Równie liczną była grupa gospodarstw średnio małych o wielkości ekonomicznej 25-50 tys. Euro (30,8\%). Gospodarstwa średnio duże (50-100 tys. Euro) i duże (100-500 tys. Euro) stanowiły odpowiednio $20,2 \%$ i $8,9 \%$. Stosunkowo najmniejszy udział posiadały gospodarstwa bardzo małe (do 8 tys. Euro - udział 5,3\%) i bardzo duże (powyżej 100 tys. Euro - udział 0,8\%). W tej ostatniej grupie znajdowały się zarówno gospodarstwa indywidualne, jak i te posiadające osobowość prawną.

Zakres zróżnicowania wyników produkcyjnych i ekonomicznych poszczególnych grup gospodarstw wydzielonych ze względu na wielkość ekonomiczną przedstawia tabela 1.

Tabela 1. Charakterystyka gospodarstw według grup wielkości ekonomicznej w 2016 roku

\begin{tabular}{|c|c|c|c|c|c|c|c|}
\hline \multirow[b]{2}{*}{ Wyszczególnienie } & \multirow[b]{2}{*}{ Ogółem } & \multicolumn{6}{|c|}{ Wielkość ekonomiczna gospodarstwa } \\
\hline & & $\begin{array}{c}\text { do } 8 \\
\text { tys. } \\
\text { Euro }\end{array}$ & $\begin{array}{c}8-25 \\
\text { tys. } \\
\text { Euro }\end{array}$ & $\begin{array}{c}25-50 \\
\text { tys. } \\
\text { Euro }\end{array}$ & $\begin{array}{c}\text { 50-100 } \\
\text { tys. } \\
\text { Euro }\end{array}$ & $\begin{array}{c}100-500 \\
\text { tys. } \\
\text { Euro }\end{array}$ & $\begin{array}{c}\text { powy- } \\
\text { żej } 500 \\
\text { tys. } \\
\text { Euro }\end{array}$ \\
\hline Liczba gospodarstw & 12302 & 649 & 4188 & 3793 & 2474 & 1098 & 100 \\
\hline Powierzchnia UR w ha & 19,5 & 8,0 & 15,1 & 26,8 & 44,8 & 99,4 & 742,5 \\
\hline Nakłady pracy w AWU na 1 gosp. & 1,68 & 1,24 & 1,63 & 1,94 & 2,27 & 4,34 & 24,27 \\
\hline Plony pszenicy $\mathrm{w} \mathrm{dt} / \mathrm{ha}$ & 53,7 & 44,3 & 48,9 & 52,2 & 54,7 & 59,3 & 61,4 \\
\hline Wydajność mleczna krów w litr. & 5545 & 3049 & 3976 & 5149 & 6286 & 7471 & 9459 \\
\hline Produkcja zwierz. na 1 LU & 4493 & 3404 & 3292 & 3786 & 4458 & 6599 & 6264 \\
\hline Koszty ogółem na 1 ha & 5897 & 3636 & 4377 & 5395 & 6251 & 9811 & 9977 \\
\hline Koszt czynników zewnęt. na 1 ha & 546 & 135 & 241 & 297 & 429 & 1074 & 1963 \\
\hline
\end{tabular}

Źródło: obliczenia własne na podstawie Wyniki Standardowe 2016 uzyskane przez gospodarstwa rolne uczestniczące w Polskim FADN. IERiGŻ, Warszawa 2017, s. 42-49.

Wielkość ekonomiczna okazała się czynnikiem różnicującym zarówno obszar jak i wyniki produkcyjne gospodarstw. W odniesieniu do badanych gospodarstw widoczna była zależność, iż wraz ze wzrostem wielkości ekonomicznej gospodarstw zwiększała się powierzchnia UR. Gospodarstwa o wielkości ekonomicznej do 8 tys. Euro liczyły średnio 8,0 ha. W przypadku gospodarstw o wielkości ekonomicznej 50-100 tys. Euro ich obszar wynosił 44,8 ha.

Obszar jest tradycyjnym miernikiem wielkości gospodarstwa rolnego powszechnie uznawanym $\mathrm{w}$ literaturze przedmiotu ${ }^{6}$. Powierzchnia użytków rolnych gospodarstwa determinuje kształtowanie się podstawowych relacji produkcyjno-ekonomicznych.

\footnotetext{
${ }^{6}$ J.S. Zegar B. Chmielewska: Dochody ludności wiejskiej: źródła, zróżnicowanie i zakres ubóstwa. (w:) Raport o stanie wsi. Polska wieś 2016. Wyd. Naukowe SCHOLAR, Warszawa 2016, s. 129-149.
} 
Wzrost wielkości ekonomicznej gospodarstwa wpływał także na zwiększenie nakładów pracy w AWU. Sprzyjał on także osiaganiu wyższych plonów pszenicy i większej wydajności mlecznej krów. W gospodarstwach o wielkości ekonomicznej powyżej 500 tys. Euro wydajność mleczna krów była ponad trzykrotnie wyższa niż w tych o wielkości ekonomicznej poniżej 8 tys. Euro.

Jednym z mierników pozwalających mierzyć stopień intensywności produkcji jest wielkość nakładów w przeliczeniu na 1 ha. W analizowanych gospodarstwach zarówno koszty ogółem jak i koszt czynników zewnętrznych rosły wraz ze wzrostem potencjału ekonomicznego.

\section{Oddziaływanie wielkości ekonomicznej na zakres wsparcia gospo- darstw środkami pochodzącymi z WPR UE}

Wielkość ekonomiczna gospodarstw rolnych określana jest sumą Standardowych Produkcji uzyskanych ze wszystkich działalności rolniczych występujących w danym gospodarstwie rolnym i wyrażana jest bezpośrednio w euro. Pole obserwacji Polskiego FADN obejmuje gospodarstwa rolne o minimalnej wielkości ekonomicznej 4000 euro ${ }^{7}$.

Dokonany podział na grupy wydzielone ze względu na wielkość ekonomiczną pozwolił ukazać zakres zróżnicowania sytuacji dochodowej w badanych gospodarstwach (rysunek 1).

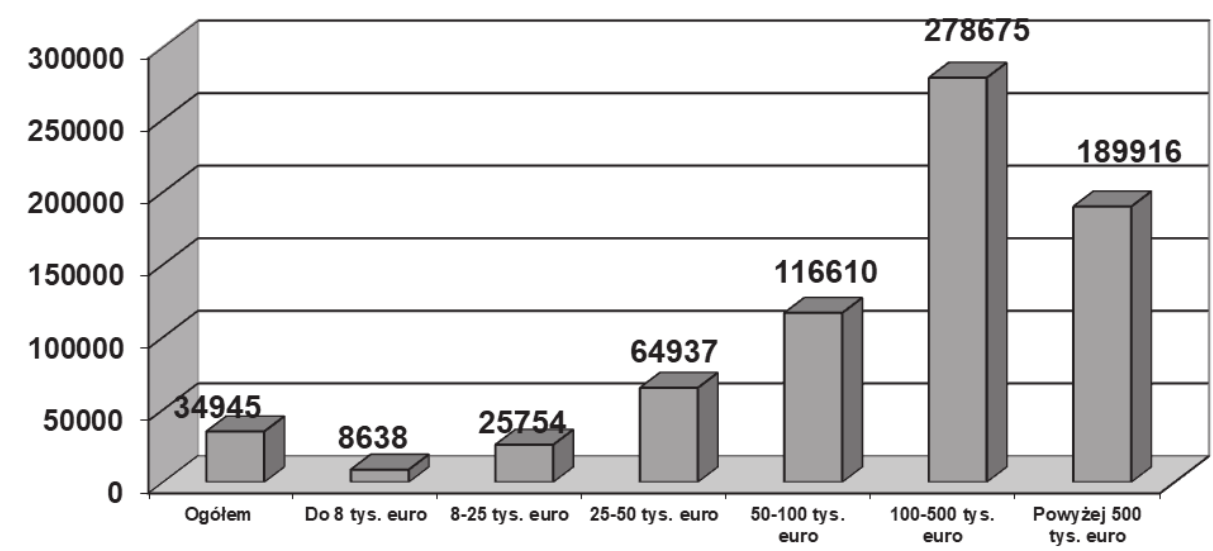

Rysunek 1. Poziom dochodu z gospodarstwa rolniczego według wielkości ekonomicznej w 2016 roku [w zł]

Źródło: obliczenia własne na podstawie Wyniki Standardowe 2016 uzyskane przez gospodarstwa rolne uczestniczące w Polskim FADN. IERiGŻ, Warszawa 2017, s. 57.

Poziom dochodu pochodzącego z działalności rolniczej w gospodarstwach prowadzących rachunkowość rolną dla potrzeb IERiGŻ w 2016 roku wynosił średnio 34945 zł. W przeliczeniu na 1 ha UR była to kwota 1792 zł. W gospodarstwach o wielkości eko-

${ }^{7}$ Z. Florianczyk, B Malanowska, D. Osuch, M. Bocian: Opis realizacji planu wyboru próby gospodarstw rolnych dla Polskiego FADN. IERiGŻ, Warszawa 2017, 9-15. 
nomicznej do 8 tys. Euro ta kategoria dochodu wynosiła 8638 zł. Zgodnie z oczekiwaniami wraz ze wzrostem wielkości ekonomicznej poprawie ulegała także sytuacja ekonomiczna. Poziom dochodu pochodzącego $\mathrm{z}$ działalności rolniczej w gospodarstwach o wielkości ekonomicznej 100-500 tys. Euro wynosił już 278675 zł. W gospodarstwach o wielkości ekonomicznej powyżej 500 tys. Euro w 2016 roku dochód wyniósł 189916 zł.

Na sytuacje ekonomiczna gospodarstw wpływ miały także instrumenty Wspólnej Polityki Rolnej UE. Wielkość płatności bezpośrednich do gruntów rolnych w gospodarstwach prowadzących rachunkowość rolną dla potrzeb IERiGŻ w 2016 roku wynosiła średnio 8886 zł. Udział tych płatności w ogólnej kwocie środków Wspólnej Polityki Rolnej UE przekazywanych do tych gospodarstw stanowił 70,3\%. Dla porównania w 2014 udział ten wynosił 76,4\%.

Zakres zróżnicowania poziomu płatności bezpośrednich do gruntów rolnych analizowanych gospodarstw w zależności od wielkości ekonomicznej gospodarstwa przedstawia tabela 2.

Tabela 2. Wielkość wsparcia środkami WPR UE według wielkości ekonomicznej gospodarstwa w roku 2016

\begin{tabular}{|c|c|c|c|c|c|c|c|}
\hline \multirow[b]{2}{*}{ Wyszczególnienie } & & \multicolumn{6}{|c|}{ Wielkość ekonomiczna gospodarstwa } \\
\hline & Ogółem & $\begin{array}{c}\text { do } 8 \\
\text { tys. } \\
\text { Euro }\end{array}$ & $\begin{array}{l}8-25 \\
\text { tys. } \\
\text { Euro }\end{array}$ & $\begin{array}{c}25-50 \\
\text { tys. } \\
\text { Euro }\end{array}$ & $\begin{array}{c}\text { 50-100 } \\
\text { tys. } \\
\text { Euro }\end{array}$ & $\begin{array}{c}\text { 100-500 } \\
\text { tys. } \\
\text { Euro }\end{array}$ & $\begin{array}{c}\text { powyżej } \\
500 \text { tys. } \\
\text { Euro }\end{array}$ \\
\hline & \multicolumn{7}{|c|}{ W zł na 1 gospodarstwo } \\
\hline $\begin{array}{l}\text { Płatności bezpośrednie do grun- } \\
\text { tów rolnych }\end{array}$ & 8886 & 3545 & 6910 & 12896 & 20616 & 45827 & 342517 \\
\hline Płatności z tytułu ONW & 1758 & 1083 & 1774 & 2710 & 3330 & 3470 & 4480 \\
\hline Płatności rolno-środowiskowe & 1415 & 843 & 1257 & 1701 & 3353 & 5312 & 22496 \\
\hline $\begin{array}{l}\text { Inne dopłaty do rozwoju obsza- } \\
\text { rów wiejskich }\end{array}$ & 580 & 71 & 1050 & 721 & 206 & 321 & 194 \\
\hline $\begin{array}{l}\text { Łącznie środki } \\
\text { ramach WPR UE }\end{array}$ & 12639 & 5542 & 10991 & 17428 & 27505 & 54930 & 369687 \\
\hline
\end{tabular}

Źródło: obliczenia własne na podstawie Wyniki Standardowe 2016 uzyskane przez gospodarstwa rolne uczestniczące w Polskim FADN. IERiGŻ, Warszawa 2017, s. 56-58.

Średnia wielkość środków pochodzących z płatności bezpośrednich w gospodarstwach o wielkości ekonomicznej do 8 tys. Euro wynosiła $3545 \mathrm{zł}$. Wraz ze wzrostem wielkości ekonomicznej gospodarstwa rosła także wielkość płatności bezpośrednich do gruntów rolnych. W gospodarstwach o wielkości ekonomicznej 50-100 tys. Euro ta forma płatności wynosiła 20616 zł, a w gospodarstwach o wielkości ekonomicznej powyżej 500 tys. Euro aż 342517 zł. Wynikało to ze zróżnicowania obszarowego gospodarstw.

Istotnym elementem oddziaływania ze strony Wspólnej Polityki Rolnej UE jest wsparcie działalności rolniczej na obszarach o niekorzystnych warunkach gospodarowania. Ma ono na celu udzielenie pomocy finansowej gospodarstwom rolnym położonym na terenach, na których produkcja rolnicza jest utrudniona ze względu na warunki naturalne. Płatności przyznawane dla gospodarstw z tytułu ONW mają przeciwdziałać wyludnianiu się obszarów wiejskich i zatracaniu ich rolniczego charakteru.

Wielkość płatności z tytułu ONW w gospodarstwach prowadzących rachunkowość rolną dla potrzeb IERiGŻ w 2016 roku wynosiła średnio 1758 zł. Również i w tym przy- 
padku wielkość ekonomiczna okazała się czynnikiem różnicującym wysokość tej płatności.

W gospodarstwach o wielkości ekonomicznej do 8 tys. Euro średnia kwota płatności z tytułu ONW wyniosła 1083 zł. Wraz ze wzrostem wielkości ekonomicznej gospodarstwa rosła także wielkość płatności z tytułu ONW. W gospodarstwach o wielkości ekonomicznej 50-100 tys. Euro ta forma płatności wynosiła $3330 \mathrm{zł}$

Poza środkami z płatności bezpośrednich i płatności z tytułu ONW do analizowanych gospodarstw trafiały także dopłaty rolno-środowiskowe oraz dopłaty do rozwoju obszarów wiejskich. Kwoty przypadające z tych źródeł średnio na gospodarstwo wynosiły w 2016 roku odpowiednio 1415 zł i 580 zł. Najwyższe kwoty płatności rolnośrodowiskowych otrzymały gospodarstwa o wielkości ekonomicznej powyżej 500 tys. Euro (22496 zł). W przypadku dopłat do rozwoju obszarów wiejskich największe kwoty skierowano do gospodarstw małych o wielkości ekonomicznej 8-25 tys. Euro (średnio na gospodarstwo $1050 \mathrm{zt})$.

Środki przekazywane w ramach Wspólnej Polityki Rolnej nie pozostają obojętne na poziom dochodów pochodzących z produkcji rolniczej. W odniesieniu do analizowanych gospodarstw ogólna kwota wsparcia w ramach WPR UE w 2016 roku stanowiła 36,2\% dochodu z gospodarstwa rolniczego. Spośród różnych form pomocy najbardziej istotne oddziaływanie na sytuację dochodową rolników miały płatności bezpośrednie do gruntów rolnych oraz płatności z tytułu ONW (rysunek 2).

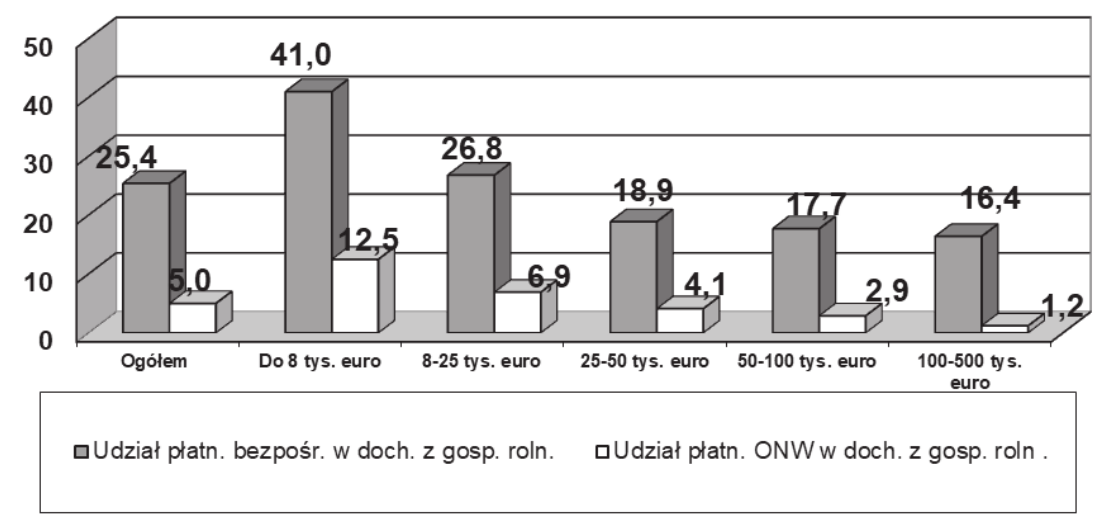

Rysunek 2. Udział płatności bezpośrednich i płatności ONW w dochodzie z gospodarstwa rolniczego według wielkości ekonomicznej w 2016 roku [w \%]

Źródło: obliczenia własne na podstawie Wyniki Standardowe 2016 uzyskane przez gospodarstwa rolne uczestniczące w Polskim FADN. IERiGŻ, Warszawa 2017, s. 56-58.

W gospodarstwach do 8 tys. Euro płatności bezpośrednie stanowiły 41,0\%. W kolejnych grupach wraz ze wzrostem wielkości ekonomicznej zakres oddziaływania płatności bezpośrednich na dochody rolnicze systematycznie malał. W gospodarstwach o wielkości ekonomicznej 8-25 tys. Euro wynosił on $26,8 \%$ a w gospodarstwach o wielkości 50-100 tys. Euro odpowiednio 17,7\%. 
W przypadku płatności z tytułu przynależności do obszarów o niekorzystnych warunkach gospodarowania największy ich udział w relacji do dochodu z gospodarstwa rolniczego występował $\mathrm{w}$ gospodarstwach o wielkości ekonomicznej do 8 tys. Euro $(12,5 \%)$. Zdecydowanie najsłabsze oddziaływanie płatności z tytułu ONW na wyniki ekonomiczne miały miejsce w przypadku gospodarstw o wielkości ekonomicznej 100500 tys. Euro.

\section{Wielkość i struktura majątku}

Spośród trzech podstawowych czynników produkcji w rolnictwie kapitał zasługuje na szczególną uwagę. Wynika to m.in. z faktu, iż czynnik ten ma właściwości zarówno zastępowania (substytucji), jak i wspomagania pozostałych czynników wytwórczych. Ma on również właściwości bezpośredniego oddziaływania na wielkość produkcji a $\mathrm{w}$ konsekwencji i wielkość dochodów gospodarstw ${ }^{8}$. Wyposażenie gospodarstw w środki trwałe odgrywa ważną rolę w kształtowaniu się wyników ekonomicznych i sposobów zarządzania (tabela 3 ).

Tabela 3. Wielkość i struktura aktywów trwałych według wielkości ekonomicznej gospodarstwa w roku 2016

\begin{tabular}{|c|c|c|c|c|c|c|c|}
\hline \multirow[b]{2}{*}{ Wyszczególnienie } & & \multicolumn{6}{|c|}{ Wielkość ekonomiczna gospodarstwa } \\
\hline & Ogółem & $\begin{array}{l}\text { do } 8 \\
\text { tys. } \\
\text { Euro }\end{array}$ & $\begin{array}{l}8-25 \\
\text { tys. } \\
\text { Euro }\end{array}$ & $\begin{array}{c}25-50 \\
\text { tys. } \\
\text { Euro }\end{array}$ & $\begin{array}{c}\text { 50-100 } \\
\text { tys. } \\
\text { Euro }\end{array}$ & $\begin{array}{c}\text { 100-500 } \\
\text { tys. } \\
\text { Euro }\end{array}$ & $\begin{array}{c}\text { powyżej } \\
500 \text { tys. } \\
\text { Euro }\end{array}$ \\
\hline & \multicolumn{7}{|c|}{ Wartość w zł na 1 gospodarstwo } \\
\hline Aktywa trwałe & 648798 & 308618 & 550945 & 992179 & 1611870 & 3092174 & 8334653 \\
\hline Ziemia i uprawy trwałe & 373977 & 193014 & 333499 & 563334 & 897346 & 1616780 & 2789790 \\
\hline Budynki i budowle & 156531 & 85187 & 127142 & 210760 & 309800 & 808147 & 3554484 \\
\hline Maszyny i urządzenia & 102953 & 27763 & 80386 & 183723 & 343962 & 607455 & 1524169 \\
\hline \multirow[t]{2}{*}{ Stado podstawowe } & 15337 & 2655 & 9917 & 34361 & 60762 & 59793 & 466210 \\
\hline & \multicolumn{7}{|c|}{ Struktura $\mathrm{w} \%$} \\
\hline Aktywa trwałe & 100,0 & 100,0 & 100,0 & 100,0 & 100,0 & 100,0 & 100,0 \\
\hline Ziemia i uprawy trwałe & 57,6 & 62,5 & 60,5 & 56,8 & 55,7 & 52,3 & 33,5 \\
\hline Budynki i budowle & 24,1 & 27,6 & 23,1 & 21,2 & 19,2 & 26,1 & 42,6 \\
\hline Maszyny i urządzenia & 15,9 & 9,0 & 14,6 & 18,5 & 21,3 & 19,6 & 18,3 \\
\hline Stado podstawowe & 2,4 & 0,9 & 1,8 & 3,5 & 3,8 & 1,9 & 5,6 \\
\hline
\end{tabular}

Źródło: obliczenia własne na podstawie Wyniki Standardowe 2016 uzyskane przez gospodarstwa rolne uczestniczące w Polskim FADN. IERiGŻ, Warszawa 2017, s. 57-58.

Aktywa trwałe stanowią najważniejszy element majątku podmiotu gospodarczego. Cechą charakterystyczną jest ich długi okres użytkowania, dzięki któremu przenoszą swoją wartość na wyroby gotowe lub usługi, zachowując jednocześnie swoją postać naturalną przez cały okres eksploatacji. Z kolei stosowne wyposażenie jednostki w środki trwałe oraz właściwe ich wykorzystanie warunkują ciagłość działalności gospodarczej i dalszy rozwój. Cechą wyróżniającą środki trwałe spośród reszty

\footnotetext{
${ }^{8}$ K. Karbowiak: Majątek trwały a zróżnicowanie dochodów rolniczych w gospodarstwach rodzinnych. (w:) Zróżnicowanie dochodowe rodzin rolniczych w Polsce. A.P. Wiatrak[red.], wyd. SGGW, Warszawa 1998, s. 149.
} 
składników majątku, jest ich forma rzeczowa i przewidywany czas ekonomicznej użyteczności dłuższy niż jeden rok ${ }^{9}$.

W odniesieniu do analizowanych gospodarstw widoczna była zależność, iż wraz ze wzrostem wielkości ekonomicznej zwiększała się wartość aktywów trwałych. Zależność ta dotyczyła także składników tworzących aktywa trwałe, to jest: ziemi i upraw trwałych, budynków i budowli oraz maszyn i urządzeń. Brak tego typu zależności dotyczył jedynie stada podstawowego.

W strukturze aktywów trwałych pozycję dominująca posiadała ziemia i uprawy trwałe. Sytuacja ta nie dotyczyła grupy gospodarstw o wielkości ekonomicznej powyżej 500 tys. Euro. W tej grupie dominującym elementem $(42,6 \%)$ okazały się budynki i budowle. Zdecydowanie najmniejszy udział $\mathrm{w}$ tak dokonanym zestawieniu, w każdej z grup gospodarstw, miało stado podstawowe.

Druga częścią majątku podmiotu gospodarczego są aktywa obrotowe. Są one przeznaczone do zbycia lub zużycia w ciągu dwunastu miesięcy od dnia bilansowego lub w ciagu normalnego cyklu operacyjnego właściwego dla danej działalności. W rolnictwie do aktywów obrotowych zalicza się: stado obrotowe, zapasy oraz pozostałe aktywa obrotowe (tabela 4).

Tabela 4. Wielkość i struktura aktywów obrotowych według wielkości ekonomicznej gospodarstwa w roku 2016

\begin{tabular}{|c|r|r|r|r|r|r|r|r|r|}
\hline \multirow{2}{*}{ Wyszczególnienie } & \multicolumn{7}{|c|}{ Wielkość ekonomiczna gospodarstwa } \\
\cline { 2 - 9 } & Ogółem & $\begin{array}{c}\text { do } 8 \\
\text { tys. } \\
\text { Euro }\end{array}$ & $\begin{array}{c}8-25 \\
\text { tys. } \\
\text { Euro }\end{array}$ & $\begin{array}{c}25-50 \\
\text { tys. } \\
\text { Euro }\end{array}$ & $\begin{array}{c}50-100 \\
\text { tys. } \\
\text { Euro }\end{array}$ & $\begin{array}{c}100-500 \\
\text { tys. } \\
\text { Euro }\end{array}$ & $\begin{array}{c}\text { powyżej } \\
500 \text { tys. } \\
\text { Euro }\end{array}$ \\
\hline Aktywa obrotowe & \multicolumn{7}{|c|}{ Wartość w zł na 1 gospodarstwo } \\
\hline Stado obrotowe & 89487 & 28485 & 62468 & 129493 & 210658 & 524821 & 4587172 \\
\hline Zapasy produktów & 19716 & 5419 & 15301 & 33916 & 53850 & 97449 & 680815 \\
\hline Pozostałe aktywa obrotowe & 26917 & 9839 & 22126 & 42540 & 69190 & 126639 & 732578 \\
\hline & 42853 & 13226 & 25042 & 53036 & 87617 & 300733 & 3173780 \\
\hline Aktywa obrotowe & \multicolumn{7}{|c|}{ Struktura w \% } \\
\hline Stado obrotowe & 100,0 & 100,0 & 100,0 & 100,0 & 100,0 & 100,0 & 100,0 \\
\hline Zapasy produktów & 22,0 & 19,0 & 24,5 & 26,2 & 25,5 & 18,6 & 14,8 \\
\hline Pozostałe aktywa obrotowe & 30,1 & 34,5 & 35,4 & 32,8 & 32,9 & 24,1 & 16,0 \\
\hline
\end{tabular}

Źródło: obliczenia własne na podstawie Wyniki Standardowe 2016 uzyskane przez gospodarstwa rolne uczestniczące w Polskim FADN. IERiGŻ, Warszawa 2017, s. 57-58.

W odniesieniu do analizowanych gospodarstw widoczna była zależność, iż wraz ze wzrostem wielkości ekonomicznej zwiększała się wartość aktywów obrotowych. Zależność ta dotyczyła także poszczególnych składników tworzących aktywa obrotowe takich jak: stado obrotowe, zapasy oraz pozostałe aktywa obrotowe.

W strukturze aktywów obrotowych pozycję dominującą posiadały te wyszczególnione jako pozostałe aktywa obrotowe. W grupie gospodarstw o wielkości ekonomicznej powyżej 500 tys. Euro ten rodzaj aktywów stanowił aż 69,2\%. Na drugim miejscu w zestawieniu znalazły się zapasy.

9 J. Aleszczyk: Rachunkowość finansowa od podstaw, Wydawnictwo Wyższej Szkoły Bankowej, Poznań 2000, s. 111. 
Zestawiając ze sobą aktywa trwałe i aktywa obrotowe stwierdza się, iż pierwsze z nich biorą udział w wielu cyklach produkcji przez okres dłuższy niż jeden rok, z kolei drugie biorą udział tylko w jednym cyklu operacyjnym. Aktywa trwałe wymagają zamrożenia środków finansowych na dłuższy czas, z reguły przekraczający jeden rok, natomiast przy aktywach obrotowych ten okres jest krótszy i nie przekracza jednego roku. Pierwsze z nich trudno dostosowują się do zmian i są mało elastyczne, z kolei drugie łatwo dostosują się do zmian panujących na rynku. Aktywa trwałe wymagają dużego zaangażowania własnych środków finansowych, natomiast aktywa obrotowe są z reguły finansowane $\mathrm{z}$ dużym udziałem źródeł obcych, takich jak kredyty i pożyczki. Z posiadaniem pierwszych wiąże się duże ryzyko gospodarcze, zaś w drugim przypadku to ryzyko jest niewielkie. W końcu aktywa trwałe pośrednio wpływają na tworzenie wyniku finansowego. $\mathrm{Z}$ kolei aktywa obrotowe bezpośrednio uczestniczą $\mathrm{w}$ generowaniu przychodów, a co za tym idzie także wyników finansowych ${ }^{10}$. Strukturę aktywów ogółem według wielkości ekonomicznej gospodarstw w 2016 roku przedstawia rysunek 3 .

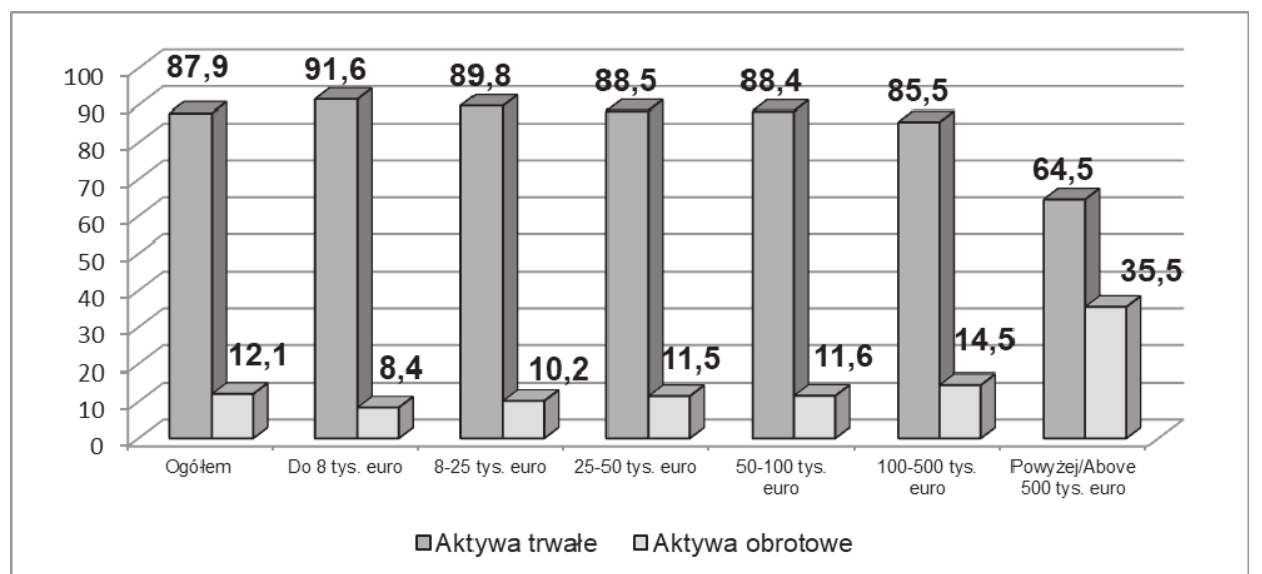

Rysunek 3. Struktura aktywów ogółem gospodarstw według wielkości ekonomicznej w 2016 roku $[\mathrm{w} \%]$

Źródło: obliczenia własne na podstawie Wyniki Standardowe 2016 uzyskane przez gospodarstwa rolne uczestniczące w Polskim FADN. IERiGŻ, Warszawa 2017, s. 56-58.

W strukturze wartościowej aktywów ogółem pozycję dominującą posiadały aktywa trwałe. Średnio w badanych gospodarstwach ich udział wynosił w 2016 roku 87,9\%. W odniesieniu do analizowanych gospodarstw widoczna była zależność, iż wraz ze wzrostem wielkości ekonomicznej zwiększał się udział aktywów obrotowych. Dla gospodarstw o wielkości ekonomicznej do 8 tys. Euro wynosił on $8.4 \%$. W gospodarstwach o wielkości ekonomicznej powyżej 500 tys. Euro udział środków obrotowych stanowił już 35,5\% aktywów ogółem.

${ }^{10}$ W. Gabrusewicz, P. Gabrusewicz: Roczne sprawozdanie finansowe przedsiębiorstwa, PWE, Warszawa 2015, s. 62-63. 


\section{Ocena sprawności zarządzania majątkiem trwałym i obrotowym w badanych podmiotach}

Oceny sprawności zarządzania majątkiem można dokonywać na podstawie wielu kryteriów. Potencjał wytwórczy gospodarstwa rolnego tworzą trzy podstawowe czynniki produkcji: ziemia, praca i kapitał. Czynniki te oraz występujące między nimi relacje określają rozmiary możliwej do osiągnięcia produkcji i dochodu. Efektywność wykorzystania poszczególnych zasobów określono za pomocą produktywności i dochodowości ziemi, pracy i kapitału (tabela 5).

Tabela 5. Efektywność wykorzystania zasobów według wielkości ekonomicznej gospodarstwa w roku 2016

\begin{tabular}{|l|r|r|r|r|r|r|r|r|r|}
\hline \multirow{2}{*}{ Wyszczególnienie } & & \multicolumn{8}{|c|}{ Wielkość ekonomiczna gospodarstwa } \\
\cline { 2 - 9 } & Ogółem & $\begin{array}{c}\text { do } 8 \\
\text { tys. } \\
\text { Euro }\end{array}$ & $\begin{array}{c}8-25 \\
\text { tys. } \\
\text { Euro }\end{array}$ & $\begin{array}{c}25-50 \\
\text { tys. } \\
\text { Euro }\end{array}$ & $\begin{array}{c}50-100 \\
\text { tys. } \\
\text { Euro }\end{array}$ & $\begin{array}{c}100-500 \\
\text { tys. } \\
\text { Euro }\end{array}$ & $\begin{array}{c}\text { powyżej } \\
500 \text { tys. } \\
\text { Euro }\end{array}$ \\
\hline & \multicolumn{7}{|c|}{ Produktywność w zł na 1 gospodarstwo } \\
\hline Produktywność ziemi & 6441 & 3577 & 4724 & 6359 & 7484 & 11540 & 9409 \\
\hline Produktywność pracy & 74758 & 23075 & 43760 & 87851 & 147709 & 263695 & 287847 \\
\hline Produktywność kapitału & 170 & 85 & 116 & 152 & 184 & 317 & 541 \\
\hline & \multicolumn{7}{|c|}{ Dochodowość w zł na 1 gospodarstwo } \\
\hline Dochodowość ziemi & 1792 & 1080 & 1706 & 2423 & 2603 & 2803 & 255 \\
\hline Dochodowość pracy & 20801 & 6966 & 15800 & 33473 & 51370 & 64211 & 7825 \\
\hline Dochodowość kapitału & 47 & 26 & 40 & 58 & 64 & 77 & 15 \\
\hline
\end{tabular}

Źródło: obliczenia własne na podstawie Wyniki Standardowe 2016 uzyskane przez gospodarstwa rolne uczestniczące w Polskim FADN. IERiGŻ, Warszawa 2017, s. 57-58.

Pojęcia produktywności i dochodowości oznaczają wielkości produkcji i dochodu w przeliczeniu na jednostkę czynnika produkcji wyrażone w pieniądzu. Określając produktywność ziemi użytkowanej rolniczo wartością produkcji rolniczej na 1 ha UR można zauważyć, że wśród analizowanych gospodarstw najwyższą jej wartość (11540 zł) odnotowano w gospodarstwach o wielkości ekonomicznej z przedziału 100-500 tys. Euro. Miało to związek ze skalą intensywności produkcji prowadzonej w tych gospodarstwach. W odniesieniu do produktywności pracy - mierzonej wartością produkcji rolniczej przypadającej na jednostkę przeliczeniowa pracy (AWU) oraz produktywności kapitału - wyrażonej wartością produkcji rolniczej przypadającej na 1000 zł wartości rzeczowych środków trwałych i obrotowych, w analizowanych gospodarstwach występowała zależność polegająca na wzroście ich wielkości wraz ze wzrostem wielkości ekonomicznej gospodarstwa.

Wartość produkcji rolniczej osiaganej przez poszczególne typy analizowanych gospodarstw w sposób oczywisty determinowała ich wyniki ekonomiczne. Dochodowość ziemi w gospodarstwach o wielkości ekonomicznej 100-500 tys. Euro była 2,6 razy wyższa niż w gospodarstwach o wielkości ekonomicznej do 8 tys. Euro. Ten sam typ relacji w odniesieniu do dochodowości pracy wynosił 9,2 razy a w przypadku dochodowości kapitału 2,9 razy.

Istotnym parametrem oceny zdolności gospodarstw do rozwoju jest wielkość wyniku finansowego netto. Jest on rozumiany jako różnica między dochodem $\mathrm{z}$ 
rodzinnego gospodarstwa rolnego a kosztami pracy własnej rolnika i jego rodziny (tabela 6).

Tabela 6. Wynik finansowy netto i parytet dochodowy według wielkości ekonomicznej gospodarstwa w roku 2016

\begin{tabular}{|l|r|r|r|r|r|r|r|r|}
\hline & & \multicolumn{7}{|c|}{ Wielkość ekonomiczna gospodarstwa } \\
\cline { 2 - 9 } Wyszczególnienie & Ogółem & $\begin{array}{c}\text { do } 8 \\
\text { tys. } \\
\text { Euro }\end{array}$ & $\begin{array}{c}8-25 \\
\text { tys. } \\
\text { Euro }\end{array}$ & $\begin{array}{c}25-50 \\
\text { tys. } \\
\text { Euro }\end{array}$ & $\begin{array}{c}50-100 \\
\text { tys. } \\
\text { Euro }\end{array}$ & $\begin{array}{c}100-500 \\
\text { tys. } \\
\text { Euro }\end{array}$ & $\begin{array}{c}\text { powyżej } \\
500 \text { tys. } \\
\text { Euro }\end{array}$ \\
\hline & \multicolumn{7}{|c|}{ w zł na 1 gospodarstwo } \\
\hline Koszt pracy własnej w zł & 50105 & 40090 & 52445 & 63117 & 67780 & 64004 & 20122 \\
\hline Wynik finansowy netto w zł & -15160 & -71542 & -26691 & 1820 & 48830 & 214671 & 169794 \\
\hline $\begin{array}{l}\text { Dochód z działalności rolniczej } \\
\text { na 1 godz. pracy własnej }\end{array}$ & 10,66 & 3,29 & 7,51 & 15,73 & 26,30 & 66,57 & 144,31 \\
\hline Parytet dochodowy & 0,69 & 0,21 & 0,49 & 1,02 & 1,72 & 4,35 & 9,44 \\
\hline
\end{tabular}

Źródło: obliczenia własne na podstawie Wyniki Standardowe 2016 uzyskane przez gospodarstwa rolne uczestniczące w Polskim FADN. IERiGŻ, Warszawa 2017, s. 57-58.

Koszty pracy rolnika zostały obliczone jako iloczyn nakładów pracy własnej wyrażonej w godzinach i stawki parytetowej. Stawka ta w 2016 roku wynosiła 15,29 zł i odpowiadała średniorocznemu wynagrodzeniu netto w gospodarce narodowej określonemu przez GUS ${ }^{11}$. Średnio na jedno analizowane gospodarstwo koszty pracy własnej wyniosły $50105 \mathrm{zl}$.

Przewaga kosztów pracy własnej rolnika nad dochodem wystąpiła w gospodarstwach o wielkości ekonomicznej 25 tys. Euro i poniżej. Konsekwencją tego był ujemny wynik finansowy netto. Dodatnią jego wartość odnotowano w gospodarstwach o wielkości ekonomicznej powyżej 25 tys. Euro. Ten rodzaj gospodarstw w literaturze przedmiotu określany bywa jako gospodarstwa rozwojowe ${ }^{12}$. Ich właściwe zarządzanie aktywami trwałymi i obrotowymi sprawia, iż osiągają one wyższy poziom dochodu $\mathrm{z}$ pracy $\mathrm{w}$ gospodarstwie niż dochód parytetowy. Parytet dochodowy obliczono jako relację dochodu $\mathrm{z}$ rodzinnego gospodarstwa w przeliczeniu na 1 godzinę pracy własnej do stawki parytetowej określonej według GUS.

Poziom dochodu z rodzinnego gospodarstwa rolnego decyduje o konkurencyjności tych podmiotów. Im wyższy jest jego poziom, tym większa skłonność rolników do rozwijania gospodarstwa poprzez inwestowanie w środki trwałe. Prowadzenie działalności inwestycyjnej w gospodarstwach rolnych jest jednym $\mathrm{z}$ ważniejszych mierników przy ocenie perspektyw rozwoju. Sprawne i efektywne funkcjonowanie gospodarstw rolnych nie jest możliwe bez wprowadzania innowacyjnych rozwiązań i inwestowania w trwałe środki produkcji. Prowadzi to do poprawy efektywności ogółu posiadanych czynników wytwórczych.

Działalność inwestycyjna świadczy o sytuacji ekonomicznej i jest wyrazem właściwie prowadzonego procesu zarządzania majątkiem w gospodarstwie rolnym. O rzeczywistym przyroście inwestycji informuje wartość inwestycji netto. W przypadku

\footnotetext{
${ }^{11}$ A. Skarżyńska: Koszty jednostkowe i dochody wybranych produktów w 2016 roku -wyniki badań w systemie AGROKOSZTY. Zagadnienia Ekonomiki Rolnej nr 2 (355), Warszawa 2018, 140-142.

${ }^{12}$ Z Gołaś: Uwarunkowania rentowności kapitału własnego w rolnictwie. Zagadnienia Ekonomiki Rolnej nr 4, Warszawa 2008 76-89.
} 
gdy wartość ta jest ujemna oznacza to, że następuje w nich dekapitalizacja majątku trwałego. Świadczy o tym również ujemna stopa reprodukcji majątku trwałego. Można przypuszczać, wówczas że wartość podejmowanych inwestycji jest zbyt mała i nie rekompensuje utraty wartości majątku na wskutek jego amortyzacji (tabela 7).

Tabela 7. Charakterystyka działalności inwestycyjnej i sytuacji finansowej gospodarstw według grup wielkości ekonomicznej w 2016 roku

\begin{tabular}{|c|c|c|c|c|c|c|c|}
\hline \multirow[b]{2}{*}{ Wyszczególnienie } & \multirow[b]{2}{*}{ Ogółem } & \multicolumn{6}{|c|}{ Wielkość ekonomiczna gospodarstwa } \\
\hline & & $\begin{array}{c}\text { do } 8 \\
\text { tys. } \\
\text { Euro }\end{array}$ & $\begin{array}{c}8-25 \\
\text { tys. } \\
\text { Euro }\end{array}$ & $\begin{array}{c}25-50 \\
\text { tys. } \\
\text { Euro }\end{array}$ & $\begin{array}{c}\text { 50-100 } \\
\text { tys. } \\
\text { Euro }\end{array}$ & $\begin{array}{c}100-500 \\
\text { tys. } \\
\text { Euro }\end{array}$ & $\begin{array}{c}\text { powy- } \\
\text { żej } 500 \\
\text { tys. } \\
\text { Euro }\end{array}$ \\
\hline Inwestycje brutto (w zł na gosp.) & 11551 & 11 & 5990 & 17839 & 43896 & 153777 & 389891 \\
\hline Amortyzacja (w zł na gosp.) & 20695 & 8367 & 17073 & 30869 & 50968 & 106501 & 503622 \\
\hline Inwestycje netto (w zł na gosp.) & -9144 & -8356 & -11083 & -13030 & -7072 & 47276 & -113730 \\
\hline $\begin{array}{l}\text { Stopa reprodukcji majątku trwałe- } \\
\text { go } \mathrm{w} \%\end{array}$ & $-1,41$ & $-2,71$ & $-2,01$ & $-1,31$ & $-4,39$ & 1,52 & $-1,36$ \\
\hline $\begin{array}{l}\text { Wskaźnik rentowności kapitału } \\
\text { własnego ROE w \% }\end{array}$ & $-2,17$ & $-21,32$ & $-4,45$ & 0,17 & 2,92 & 7,17 & 1,54 \\
\hline $\begin{array}{l}\text { Wskaźnik bieżącej płynności } \\
\text { finansowej }\end{array}$ & 8,41 & 50,06 & 16,77 & 9,64 & 6,21 & 3,99 & 13,15 \\
\hline $\begin{array}{l}\text { Wskaźnik płynności przyspieszo- } \\
\text { nej }\end{array}$ & 5,88 & 32,77 & 10,83 & 6,47 & 4,17 & 3,02 & 11,06 \\
\hline
\end{tabular}

Źródło: obliczenia własne na podstawie Wyniki Standardowe 2016 uzyskane przez gospodarstwa rolne uczestniczące w Polskim FADN. IERiGŻ, Warszawa 2017, s. 57-58.

W odniesieniu do analizowanych gospodarstw tylko w przypadku tych o wielkości od 100 do 500 tys. Euro wartość inwestycji netto była dodatnia i wynosiła 47276 zł. Stopa reprodukcji majątku trwałego obliczana jako relacja wartości inwestycji brutto do wartości środków trwałych w tym przypadku wyniosła 1,52\%. Występująca reprodukcja rozszerzona świadczy o tym, że dokonuje się tutaj nie tylko proste odtworzenie zużytych środków produkcji, ale ma miejsce także zwiększenie i unowocześnienie aparatu wytwórczego.

Efektywność gospodarowania, świadczącą o jakości zarządzania, można określić także na podstawie oceny kondycji finansowej gospodarstw rolnych. Wskaźnik rentowności kapitału własnego ROE oblicza się jako relację wyniku finansowego netto i kapitału własnego. Przedstawia on zdolność gospodarstwa do wypracowania zysku netto z jednej złotówki kapitału własnego. Jest on najbardziej syntetycznym wskaźnikiem rentowności, gdyż uwzględnia wszelkie skutki decyzji i działań operacyjnych, inwestycyjnych i finansowych. Dodatnią rentownością kapitału własnego odznaczały się gospodarstwa o wielkości ekonomicznej powyżej 25 tys. Euro. Im większa jest rentowność tym lepsze są perspektywy rozwojowe gospodarstwa i więcej środków można przeznaczyć ono na zakup środków trwałych i obrotowych. Relatywnie najwyższą rentownością $(7,17 \%)$ odznaczały się gospodarstwa o wielkości od 100 do 500 tys. Euro.

O zdolności gospodarstwa do funkcjonowania na rynku informuje również wskaźnik płynności finansowej. $Z$ danych przedstawionych w tabeli 7 wynika, że we wszystkich porównywanych grupach gospodarstw wskaźnik bieżącej płynności finansowej znacząco odbiegał od wartości optymalnych (powinny one wynosić 1,5- 
$\left.2,0^{13}\right)$. Specyfika rolnictwa sprawia, iż występuje tutaj wolny obrót kapitału. Środki zainwestowane w aktywa obrotowe są zwracane dopiero po zakończonym cyklu produkcyjnym, który zazwyczaj trwa jeden rok. Nie ma wówczas możliwości wcześniejszego zbycia części tego majątku, nawet jeśli rachunek ekonomiczny na to wskazuje. Wśród analizowanych gospodarstw szczególnie wysokie wartości wskaźnika bieżącej płynności finansowej odnotowano w przypadku gospodarstw o niskim potencjale produkcyjnym. W przypadku gospodarstw o wielkości ekonomicznej z przedziału 8-25 tys. Euro wielkość wskaźnika wyniosła 16,77 a gospodarstw o wielkości ekonomicznej do 8 tys. Euro nawet 50,06. Właściciele tych gospodarstw zbyt mało inwestowali w rozwój, a zasób środków obrotowych, nie był wykorzystywany racjonalnie. Diametralnie inna sytuacja miała miejsce w przypadku gospodarstw o dużym potencjale produkcyjnym. W gospodarstwach o wielkości ekonomicznej 100-500 tys. Euro wskaźnik bieżącej płynności finansowej wynosił 3,99 a podwyższonej płynności finansowej 3,02. Właściciele ich dysponując optymalnymi zasobami środków trwałych i obrotowych posiadali świadomość inwestowania jako niezbędnego warunku utrzymania pozycji konkurencyjnej.

\section{Wnioski}

Reasumując dotychczasowe rozważania można sformułować następujące wnioski:

- Potencjał ekonomiczny gospodarstw okazał się czynnikiem różnicującym wielkość i strukturę ich majątku. Jego wartość wzrastała wraz ze wzrostem wielkości ekonomicznej gospodarstw. W strukturze wartościowej aktywów ogółem, pozycję dominująca posiadały aktywa trwałe. Średnio w badanych gospodarstwach ich udział wynosił w 2016 roku 87,9\%. W odniesieniu do analizowanych gospodarstw widoczna była zależność, iż wraz ze wzrostem wielkości ekonomicznej zwiększał się udział aktywów obrotowych. Dla gospodarstw o wielkości ekonomicznej do 8 tys. Euro wynosił on $8.4 \%$. W gospodarstwach o wielkości ekonomicznej powyżej 500 tys. Euro udział środków obrotowych stanowił już 35,5\% aktywów ogółem.

- Jednym z parametrów oceny sprawności zarządzania majątkiem była efektywność wykorzystania zasobów. W odniesieniu do produktywności kapitału - wyrażonej wartością produkcji rolniczej przypadającej na 1000 zł wartości rzeczowych środków trwałych i obrotowych, w analizowanych gospodarstwach występowała zależność polegająca na wzroście jej wielkości wraz ze wzrostem wielkości ekonomicznej gospodarstwa. Najwyższym poziomem dochodowości odznaczały się gospodarstwa o wielkości ekonomicznej 100-500 tys. Euro

- Wyrazem właściwie prowadzonego procesu zarządzania majątkiem w gospodarstwie rolnym jest działalność inwestycyjna. O rzeczywistym przyroście inwestycji informuje wartość inwestycji netto. W odniesieniu do analizowanych gospodarstw tylko w przypadku tych o wielkości od 100 do 500 tys. Euro wartość inwestycji netto była dodatnia Stopa reprodukcji majątku trwałego w tym przypadku wyniosła 1,52\%. Występująca reprodukcja rozszerzona świadczy o realnym zwiększeniu i unowocześnieniu aparatu wytwórczego.

${ }^{13}$ W. Gabrusewicz: Podstawy analizy finansowej. PWE Warszawa 2002, 250-254. 
- Efektywność gospodarowania, świadczącą o jakości zarządzania, można określić także na podstawie oceny kondycji finansowej gospodarstw rolnych. Wskaźnik rentowności kapitału własnego ROE jest najbardziej syntetycznym wskaźnikiem rentowności, gdyż uwzględnia on wszelkie skutki decyzji i działań operacyjnych, inwestycyjnych i finansowych. Dodatnią rentownością kapitału własnego odznaczały się gospodarstwa o wielkości ekonomicznej powyżej 25 tys. Euro. Relatywnie najwyższą rentownością $(7,17 \%)$ odznaczały się gospodarstwa o wielkości od 100 do 500 tys. Euro. Im większa jest rentowność, tym lepsze są perspektywy rozwojowe gospodarstwa i więcej środków można przeznaczyć na zakup poszczególnych składników majątku.

\section{Bibliografia}

Aleszczyk J.: Rachunkowość finansowa od podstaw, Wydawnictwo Wyższej Szkoły Bankowej, Poznań 2000.

Floriańczyk Z, Malanowska B., Osuch D., Bocian M.: Opis realizacji planu wyboru próby gospodarstw rolnych dla Polskiego FADN. IERiGŻ, Warszawa 2017.

Gabrusewicz W., Gabrusewicz P.: Roczne sprawozdanie finansowe przedsiębiorstwa, PWE, Warszawa 2015.

Gabrusewicz W.: Podstawy analizy finansowej. PWE Warszawa 2002.

Gołaś Z: Uwarunkowania rentowności kapitału własnego w rolnictwie. Zagadnienia Ekonomiki Rolnej nr 4, Warszawa 2008.

Goraj L., Mańko S.: Rachunkowość i analiza ekonomiczna w indywidualnym gospodarstwie rolnym. Difin, Warszawa 2009.

Grzywacz J. (red): Zarządzanie majątkiem obrotowym w przedsiębiorstwie. SGH Warszawa 2006. Karbowiak K.: Majątek trwały a zróżnicowanie dochodów rolniczych w gospodarstwach rodzinnych. (w:) Zróżnicowanie dochodowe rodzin rolniczych w Polsce. A.P. Wiatrak [red.], wyd. SGGW, Warszawa 1998.

Mańko S., Płonka R.: Struktura aktywów a wyniki działalności gospodarstw rolnych w świetle danych polskiego FADN Zagadnienia Ekonomiki Rolnej nr 4 (325) Warszawa 2010.

Niedzielski E, Fedejko B.: Zarządzanie strategiczne przedsiębiorstwem rolniczym. Wyd. ART. Olsztyn 1995,

Skarżyńska A.: Koszty jednostkowe i dochody wybranych produktów w 2016 roku -wyniki badań w systemie AGROKOSZTY. Zagadnienia Ekonomiki Rolnej nr 2 (355), Warszawa 2018.

Wyniki Standardowe 2016 uzyskane przez gospodarstwa rolne uczestniczące w Polskim FADN. IERiGŻ, Warszawa 2017,

Zegar J.S., Chmielewska B.: Dochody ludności wiejskiej: źródła, zróżnicowanie i zakres ubóstwa. (w:) Raport o stanie wsi. Polska wieś 2016. Wyd. Naukowe SCHOLAR, Warszawa 2016.

\section{Summary}

The aim of this study is to show the scope of asset management of economic entities with various economic potential. The research material was data on farms characterized by diversified economic size, which carried out agricultural accounting for the needs of the Institute of Agricultural Economics and Food Economy. The property of the holding was presented in a synthetic form as the sum of two groups of assets: fixed and current. Within the area of non-current assets, four components were analyzed and three components in the case of current assets. To assess the effects of management actions, the productivity and profitability of basic production factors were analyzed. The highest level of profitability was noted for farms with an economic size of 100-500 thousand. Euro. An important parameter of the efficiency of management was the return on equity 
ratio of ROE. Its positive value was characterized by farms with an economic size above 25,000. Euro. Higher profitability improved the development prospects of the farm and made more money available for the purchase of individual assets.

Key words: fixed and current assets, economic size, property management, management efficiency.

Informacja o autorach

Dr inż. Agata Marcysiak

Katedra Ekonomii

Wydział Nauk Ekonomicznych i Prawnych

Uniwersytet Przyrodniczo-Humanistyczny w Siedlcach

ul Żytnia 17/19

08-110 Siedlce

agata.marcysiak@uph.edu.pl

ORCID: 0000-0003-2534-9877

Dr inż. Adam Marcysiak

Katedra Logistyki

Wydział Nauk Ekonomicznych i Prawnych

Uniwersytet Przyrodniczo-Humanistyczny w Siedlcach

ul Żytnia 17/19

08-110 Siedlce

adam.marcysiak@uph.edu.pl

ORCID: 0000-0002-3132-8565 